\title{
Case series of outcome of newborn babies exposed to Lassa fever virus infection
}

\author{
Dorathy Chinwe Obu, Obumneme Benaiah Ezeanosike, Samuel Amechi Nwukor \\ Department of Paediatrics, Alex Ekwueme Federal University Teaching Hospital Abakaliki, Ebonyi State,
}

\begin{abstract}
Lassa fever (LF) is an acute viral hemorrhagic fever caused by the Lassa virus, a zoonotic infection transmitted by the infected multimammate mouse which is endemic in West African countries. It affects all ages contributing to high maternal and neonatal mortality rates. Neonates are at risk of vertical and horizontal transmission of Lassa virus. We report a series of six newborns, three of whom were delivered to Lassa fever positive mothers and were managed as exposed babies while the remaining three were diagnosed with neonatal Lassa fever. None of the babies exposed to the virus became infected and two of these exposed babies had a positive outcome. All the babies with neonatal Lassa fever died days
\end{abstract}

Correspondence: Dorathy Chinwe Obu, Alex Ekwueme Federal University Teaching Hospital Abakaliki, PMB 102, Abakaliki, Ebonyi State, Nigeria.

E-mail: obudora@yahoo.com

Key words: Lassa fever; mortality; newborns; outcome.

Contributions: NS performed case summary. OD and EO wrote manuscript draft. All authors reviewed, edited and made final approval of the manuscript.

Conflict of interest: The authors declare no conflict of interest.

Funding: None.

Acknowledgments: We are grateful to the mothers of the newborn babies who graciously accepted for the case to be reported.

Ethics approval and consent to participate: Approval for the case series was obtained from Research and ethics committee of Alex Ekwueme Federal University Teaching Hospital Abakaliki.

Consent for publication: Written informed consent was obtained from a legally authorized representative(s) for anonymized patient information to be published in this article.

Availability of data and materials: Not applicable.

Received for publication: 14 July 2020

Revision received: 14 September 2020.

Accepted for publication: 18 September 2020.

This work is licensed under a Creative Commons Attribution NonCommercial 4.0 License (CC BY-NC 4.0).

${ }^{\circ}$ Copyright: the Author(s),2020

Licensee PAGEPress, Italy

Annals of Clinical and Biomedical Research 2020; 1:97

doi:10.4081/acbr.2020.97 after birth even before confirming the diagnosis and initiating ribavirin treatment. This highlights the need for prompt diagnosis in utero with treatment of mother before delivery to improve the neonatal outcome. Also, the need to commence intravenous ribavirin treatment in highly suspicious cases of neonatal Lassa fever while awaiting confirmation of the diagnosis is emphasized.

\section{Introduction}

Lassa Fever (LF) is an acute viral hemorrhagic fever caused by the Lassa virus which is zoonotic and endemic in West African countries such as Nigeria, Sierra Leone, Liberia, Guinea, Mali, Togo, and Benin. ${ }^{1}$ The virus is a member of the Arenaviridae, a family of negative-sense, single-stranded RNA virus. It was discovered in 1969 in the town of Lassa, Borno State, Nigeria. ${ }^{1,2}$ Its primary animal host is the Natal Multimammate mouse (Mastomys Natalensis), an animal indigenous to many of Sub-Saharan African countries. There are an estimated 300,000-500,000 cases of LF each year with a mortality rate of $15 \%-20 \%$ for hospitalized patients, getting as high as 50\% during epidemics and $90 \%$ in infected pregnant women and the fetuses. ${ }^{3,4}$

The virus is spread through contact with food or household items contaminated by infected rats' faeces and urine or handling of infected rats..$^{5}$ It can equally be transmitted from person to person through contact of body fluids of an infected individual. Sexual and transplacental transmission of the virus as well as transmission through infected breast milk have also been established. ${ }^{5,6}$ While there is no approved therapeutic agent for LF, the antiviral drug ribavirin has been demonstrated to reduce fatality from $55 \%$ to $5 \%$, only if administered within 6 days of the onset of symptoms. $^{7}$

Clinical data on LF in neonates are still very limited. ${ }^{6,8,9}$ In the neonatal unit of the present study facility, routine care for admitted newborns includes cord care, prophylactic vitamin K administration. Intravenous antibiotics, continuous positive pressure ventilation, caffeine citrate, surfactant, intravenous fluid is administered where indicated. Concerning newborns delivered to mothers with confirmed LF, cord and peripheral blood samples are tested for Lassa virus PCR positivity with baby separated from mother and admitted into the Hospital Virology unit observation bay. Prophylactic intravenous ribavirin treatment is usually commenced and discontinued if both samples test negative to Lassa virus PCR and baby monitored for 21 days incubation period of Lassa virus with repeat Lassa virus PCR as indicated. However, for babies with suspected LF, ribavirin treatment is only commenced after confirmation of positive Lassa RT-PCR. The hospital has a virology unit for admission of confirmed cases of LF and an observation bay for suspected cases of LF with gadgets needed for care of a newborn provided. We present a series of six newborns delivered to Lassa fever positive mothers/diagnosed of LF and managed at the Alex Ekwueme Federal Teaching Hospital Abakaliki (AEFUTHA), Nigeria, from 2019 to 2020. 


\section{Case summaries}

\section{Case \#1}

A male preterm neonate presented 6 hours after delivery to a 30-years-old Lassa reverse transcription-polymerase chain reaction (RT-PCR) positive woman, diagnosed in our facility at 32 weeks Gestational Age (GA). The mother had received two doses of intravenous ribavirin before spontaneous onset of labour. The baby had a weak cry at birth but established spontaneous regular respiration after tactile stimulation and suctioning with an Apgar score of 6 at the first minute and 9 at 5 minutes.

Physical examination showed a conscious male, afebrile, not pale, anicteric with features of moderate prematurity using new Ballard assessment method. The anthropometric parameters were birth weight $(1.7 \mathrm{~kg})$, head circumference $(32 \mathrm{~cm})$, and length (44 $\mathrm{cm})$, while the vital signs were heart rate of 158 beats per minute and the respiratory rate of 60 cycles/minute. Systemic examination did not reveal any abnormality. A diagnosis of Lassa fever exposed preterm low birth weight was made and the baby was admitted into the Hospital Virology unit for care. Incubator care alongside other care per unit protocol for preterm babies was commenced. The baby received intravenous ribavirin $16 \mathrm{mg} / \mathrm{kg}$ (25mg) 8hourly for 5 days. Breast milk substitute, intravenous ceftazidime, and sultamicillin were also started.

Lassa PCR at birth was negative. Following repeat negative RT-PCR result on the $5^{\text {th }}$ day of life, intravenous ribavirin was discontinued while other care was continued. On the $11^{\text {th }}$ day of life, the baby became progressively apneic, severely pale, and unconscious. Urgent packed cell volume done was $26 \%$ and a clinical diagnosis of intracranial hemorrhage was made. All efforts at management did not yield any positive results as the baby succumbed to death.

\section{Case \#2}

A female extremely preterm neonate was referred from a Mission hospital 3 hours after delivery to a 28-year mother at a GA of 26 weeks on account of respiratory distress. Mother had one week history of fever and one day history of bleeding per vaginum that led to precipitous labour and preterm delivery. She did not receive intravenous dexamethasone before delivery. The baby cried well at birth with an Apgar score of 8 at one minute and 9 at five minutes but developed breathing difficulty a few minutes after birth.

Physical examination showed a critically ill-looking extreme preterm female neonate using new Ballard score, in severe respiratory distress, lethargic, not pale, and not cyanosed but had pectus carinatum. The anthropometric parameters were birth weight $(0.8$ $\mathrm{kg}$ ) and head circumference $(29 \mathrm{~cm})$ while the vital signs were heart rate of 165 beats per minute and the respiratory rate of 90 cycle/minute. Other systems examined were normal. An initial diagnosis of extreme preterm extreme low birth weight with Respiratory Distress Syndrome was made. The baby was admitted and managed per unit protocol. Respiratory support was provided with continuous positive airway pressure. Intravenous ceftazidime, sultamicillin, caffeine citrate and intravenous fluid were commenced and vitamin K given prophylactically. Surfactant was prescribed but was not administered due to non-availability.

On the third day of admission, the baby started bleeding fresh blood from puncture sites, mouth and nostrils. Packed cell volume done was $28 \%$. Haemorrhagic disease of newborn and Lassa fever were suspected and a blood sample was sent for Lassa RT-PCR. The treatment dose of vitamin $\mathrm{K}$ was administered as well as packed cell transfusion. However, bleeding continued and baby died 42 hours after admission. Baby's Lassa virus RT-PCR was confirmed positive. Follow up visit to referring hospital to obtain a maternal blood sample for Lassa RT-PCR revealed that the mother was discharged from the hospital but was brought back dead two days later. Thus, Lassa RT-PCR was not obtained from the mother.

\section{Case \#3}

A 30 minutes old preterm female newborn was delivered via spontaneous vaginal delivery at GA of 35 weeks to a 28 -years-old now para 3 woman diagnosed with Lassa fever six days prior to labour. The mother was immediately commenced on intravenous Ribavirin following this diagnosis and she received 12 doses. She registered for antenatal care at a peripheral hospital and was compliant with her routine medication. Pregnancy was uneventful until 10 days before the presentation when the mother developed a fever for which she was referred to our facility, where she tested positive to Lassa RT-PCR. Her retroviral screening test and venereal research laboratory test were negative. Labour was precipitous and baby cried well at birth with Apgar score of 9 at one minute and 10 at five minutes.

Physical examination showed a female neonate with a birth weight of $2.7 \mathrm{~kg}$, head circumference $34 \mathrm{~cm}$, and length $49 \mathrm{~cm}$. Her heart rate was 120 beats per minute and the respiratory rate was 48 cycles/minute. Systemic examination showed no abnormal findings. Diagnosis of Lassa fever exposed near term neonate was made and the baby was admitted into Hospital Virology unit observation bay for further care. Breast milk substitute was commenced alongside intravenous sultamicillin and Ceftazidine, prophylactic vitamin K therapy, and cord care. Baby received a loading dose of ribavirin $89 \mathrm{mg}$ and maintenance dose was continued at $22 \mathrm{mg}$ every 12 hours for 6 days. Following the second negative RT-PCR on $7^{\text {th }}$ day of life, intravenous ribavirin was discontinued. The baby was monitored for the development of symptoms and signs of Lassa fever for the 21 days maximum incubation period of Lassa fever infection. She developed a fever and reduced milk intake on the $19^{\text {th }}$ day of life for which neonatal malaria was diagnosed and antimalarial treatment commenced. Packed cell volume done was $25 \%$ while total leucocyte count $10.5 \times 10^{9} \mathrm{~g} / \mathrm{L}$, neutrophil $10 \%$, lymphocyte $53 \%$, monocyte $36 \%$, eosinophils $2 \%$, platelet count of $462 \times 10^{9} \mathrm{~g} / \mathrm{L}$. Severe anaemia was corrected with the transfusion of the packed cells. Following the completion of antimalarial medication, the baby remained healthy and was discharged on the $25^{\text {th }}$ day of life after the third PCR done on $23^{\text {rd }}$ of life still showed a negative result.

\section{Case \#4}

A female neonate presented 5 minutes after emergency Caesarian section delivery to a 35 -year-old now para 6 mother at GA of 38 weeks +3 days. The indication for the emergency Caesarian section was previous Caesarian section and fetal distress and the amniotic fluid was thick and stained with stale-meconiumstained. Apgar score was 5 in the first minute and 8 in five minutes.

The mother registered for antenatal care in our facility and received her routine medication. Mother had five days history of fever, headache, sore throat and chest pain at GA of 36 weeks for which she was admitted and treated for malaria in pregnancy in our facility and discharged three days later following resolution of the symptoms. Labour pain started 8 days after discharge. She had no history of prolonged rupture of membrane or any other symptoms of illness.

Physical examination revealed a female neonate, in respiratory distress, afebrile $\left(36.5^{\circ} \mathrm{C}\right)$, not pale and not cyanosed. Her weight was $3.4 \mathrm{~kg}$, head circumference was $37 \mathrm{~cm}$, and length of $51 \mathrm{~cm}$. 
Her respiratory rate was 95 cycles/minute, heart rate 149 beats per minute. The initial diagnosis was Meconium Aspiration syndrome. Intravenous ceftazidime, sultamicillin, vitamin $\mathrm{K}$ and respiratory support with CPAP were commenced.

She developed seizures, periumbilical redness, sclerema hepatomegaly, and worsening respiratory distress two days into admission. The baby also started bleeding from puncture sites, bleeding time was prolonged. Lassa fever was suspected while the differential diagnosis of Vitamin K deficiency bleeding, bleeding disorder, and neonatal sepsis were considered. The Antibiotic was reviewed. Intravenous phenytoin $16.5 \mathrm{mg}$ every 12 hours was commenced. Serum electrolytes, blood culture, and lumbar puncture could not be done due to financial constraints. Exchange transfusion and fresh frozen plasma transfusion were planned but were not done for the same reason. The baby died on the third day of life after testing positive to Lassa RT-PCR sample collected on the third day of life. The mother tested negative to the Lassa RT-PCR test done twice.

\section{Case \#5}

A 12-days old female term neonate developed fever for 9 days, fast breathing for 2 days, and reduced physical activity, and seizures for one day all before presentation to our facility for expert care. The baby was delivered at a health center in a rural setting to a 25-years-old woman at the gestational age of 39 weeks. The baby cried well at birth and was discharged home the same day. She remained well until the onset of fever. Mother had a oneweek history of fever and 3 days history of premature prolonged rupture of membrane before delivery for which she took only acetaminophen and continued taking it.
On examination, the baby was critically ill, in respiratory distress, febrile $\left(38.7^{\circ} \mathrm{C}\right)$ and pale. Her respiratory rate was 73 cycles/minute and her heart rate was 140 beat per min. The central nervous system examination showed a lethargic baby with depressed primitive reflexes and global hypotonia. She also had hepatomegaly. A diagnosis of neonatal sepsis with neonatal meningitis was made. Intravenous phenytoin, cefotaxime, and sultamicillin were commenced. Lassa fever was suspected when the baby started passing bloody stool 4 hours into admission and her packed cell volume was $35 \%$. The baby died within 12 hours of admission. Following the death of the baby, the sample was sent for Lassa RTPCR which tested positive. The mother refused consent for Lassa RT-PCR

\section{Case \#6}

A 2-hours old female newborn was delivered via spontaneous vaginal delivery at GA of 39 weeks +3 days to a 27 -years-old booked $\mathrm{G}_{2} \mathrm{P}_{1}+0$ woman. The mother registered for antenatal care at our facility. The mother had a febrile illness and was diagnosed with Lassa fever at the $6^{\text {th }}$ month of pregnancy, for which ribavirin therapy was given. She was discharged later after testing negative to Lassa RT-PCR. However, ten days before delivery, she developed a fever and tested positive for Lassa RT-PCR again. Mother was commenced on ribavirin therapy before delivery of the baby. Her retroviral screening test and venereal research laboratory test were negative. Labour was induced and the baby cried well at birth with an Apgar score of 7 in the first minute and 8 in five minutes.

Physical examination showed an active female neonate. The anthropometric parameters were birth weight of $2.8 \mathrm{~kg}$, head circumference $34 \mathrm{~cm}$, and length $50 \mathrm{~cm}$ while the temperature was

Table 1. Characteristics of 6 hospitalized PCR confirmed neonatal Lassa fever.

\begin{tabular}{|c|c|c|c|c|c|c|}
\hline Variables & Case 1 & Case 2 & Case 3 & Case 4 & Case 5 & Case 6 \\
\hline $\begin{array}{l}\text { Demographics } \\
\text { Age } \\
\text { Gender }\end{array}$ & $\begin{array}{c}6 \text { hours } \\
\text { M }\end{array}$ & $\begin{array}{c}3 \text { hours } \\
\text { F }\end{array}$ & $\begin{array}{c}30 \text { minutes } \\
\mathrm{F}\end{array}$ & $\begin{array}{c}5 \text { minutes } \\
\mathrm{F}\end{array}$ & $\begin{array}{c}12 \text { days } \\
\mathrm{F}\end{array}$ & $\begin{array}{c}2 \text { hours } \\
\text { F }\end{array}$ \\
\hline $\begin{array}{l}\text { Perinatal history } \\
\text { Gestational age } \\
\text { Place of delivery } \\
\text { PROM } \\
\text { MSAF } \\
\text { Prolonged labour }\end{array}$ & $\begin{array}{l}32 \text { weeks } \\
\text { AEFUTHA } \\
\text { No } \\
\text { No } \\
\text { No }\end{array}$ & $\begin{array}{l}26 \text { weeks } \\
\text { Mission hospital } \\
\text { ND } \\
\text { ND } \\
\text { ND }\end{array}$ & $\begin{array}{l}35 \text { weeks } \\
\text { AEFUTHA } \\
\text { No } \\
\text { No } \\
\text { No }\end{array}$ & $\begin{array}{c}\text { 38weeks+ 3days } \\
\text { AEFUTHA } \\
\text { No } \\
\text { Yes } \\
\text { No }\end{array}$ & $\begin{array}{l}39 \text { weeks } \\
\text { Health centre } \\
\text { Yes } \\
\text { No } \\
\text { No }\end{array}$ & $\begin{array}{c}\text { 39weeks + 3days } \\
\text { AEFUTHA } \\
\text { No } \\
\text { No } \\
\text { No }\end{array}$ \\
\hline $\begin{array}{l}\text { Apgar score in the } 1 \text { st } \& 5 \text { th minutes of birth } \\
\text { Anthropometry } \\
\text { Weight }(\mathrm{kg}) \\
\text { Head circumference }(\mathrm{cm}) \\
\text { Length }(\mathrm{cm})\end{array}$ & $\begin{array}{l}1.7 \\
32 \\
44\end{array}$ & $\begin{array}{c}0.85 \\
29\end{array}$ & $\begin{array}{l}2.7 \\
24 \\
45\end{array}$ & $\begin{array}{l}3.4 \\
37 \\
51\end{array}$ & $\begin{array}{l}3.2 \\
36 \\
50\end{array}$ & $\begin{array}{l}2.8 \\
35 \\
50\end{array}$ \\
\hline $\begin{array}{l}\text { Clinical features } \\
\text { Fever } \\
\text { Bleeding from orifices } \\
\text { Tachypnea } \\
\text { Respiratory distress } \\
\text { Lethargy } \\
\text { Pallor } \\
\text { Seizure } \\
\text { Others }\end{array}$ & $\begin{array}{c}\text { No } \\
\text { No } \\
\text { No } \\
\text { No } \\
\text { No } \\
\text { No } \\
\text { No } \\
\text { None }\end{array}$ & $\begin{array}{l}\text { No } \\
\text { No } \\
\text { No } \\
\text { No } \\
\text { No } \\
\text { No } \\
\text { No } \\
\text { None }\end{array}$ & $\begin{array}{c}\text { Yes } \\
\text { Yes } \\
\text { Yes } \\
\text { Yes } \\
\text { Yes } \\
\text { Yes } \\
\text { No } \\
\text { Pectus } \\
\text { carinatum }\end{array}$ & $\begin{array}{c}\text { No } \\
\text { Yes } \\
\text { Yes } \\
\text { Yes } \\
\text { Yes } \\
\text { Yes } \\
\text { Yes } \\
\text { Hepatomegaly, } \\
\text { periumblical } \\
\text { redness, } \\
\text { sclerema }\end{array}$ & $\begin{array}{c}\text { Yes } \\
\text { Yes } \\
\text { Yes } \\
\text { Yes } \\
\text { Yes } \\
\text { Yes } \\
\text { Yes } \\
\text { Depressed } \\
\text { primitive } \\
\text { reflexes, } \\
\text { global hypotonia }\end{array}$ & $\begin{array}{l}\text { No } \\
\text { No } \\
\text { No } \\
\text { No } \\
\text { No } \\
\text { No } \\
\text { No } \\
\text { None }\end{array}$ \\
\hline Complications & None & $\begin{array}{c}\text { None } \\
\text { distress } \\
\text { syndrome }\end{array}$ & $\begin{array}{l}\text { Respiratory } \\
\text { aspiration }\end{array}$ & $\begin{array}{c}\text { Meconium } \\
\text { sepsis/meningitis } \\
\text { syndrome }\end{array}$ & Neonatal & None \\
\hline
\end{tabular}

*PROM: prolonged rupture of membrane; MSAF; meconium stained amniotic fluid; ND: not determined; NA: not available. 
$36.8^{\circ} \mathrm{C}$, heart rate was 130 beats per minute, and respiratory rate 46 cycles/minute. Systemic examination showed normal findings. Diagnosis of Lassa fever exposed neonate was made and the baby was admitted into virology unit observation bay for further care. Breast milk substitute was commenced alongside intravenous sultamicillin and ceftazidime, prophylactic Vitamin K therapy, and cord care. The initial Lassa PCR test was negative to peripheral blood samples but positive to the cord blood sample at birth. Baby did not receive ribavirin treatment and remained healthy. Following the second negative result of peripheral blood Lassa PCR on $7^{\text {th }}$ day of life, the baby was discharged home.

\section{Summary of the cases}

In this case series, three newborns (case 2, 4 and 5) had reverse transcription-polymerase chain reaction (RT-PCR) confirmed Lassa fever while the other three (case 1, 3 and 6) were delivered by mothers with confirmed Lassa fever and thus were exposed. Four of the newborns were delivered preterm (Tables 1, 2 and 3). In cases 1, 3 and 6 with confirmed maternal Lassa fever, their mothers were commenced on ribavirin therapy before delivery and as such, they were managed as Lassa fever exposed neonates. Interestingly, none of them contracted the virus (non disease)
(Table 3). Cases 2, 4 and 5 had clinical features suspicious of LF and were diagnosed with Lassa fever disease post mortem, thus they did not receive ribavirin therapy and therefore had a fatal outcome (Tables 1 and 2).

\section{Discussion}

Lassa fever affects people of all ages with an incubation period of 2-21days. ${ }^{5}$ Average period of clinical manifestation in all the 3 cases that had Neonatal LF was 3-4 $4^{\text {th }}$ day of life which is within the incubation period of LF. This early manifestation of symptoms may be due to the low immunity status of newborn babies. It is possible the babies with Neonatal LF had vertical transmission considering the time of infection which mirrors the time of presentation of early neonatal sepsis, although possibility of horizontal transmission cannot be excluded. The commonest source of earlyonset neonatal sepsis is the vertical transmission, hence a vertical transmission of Lassa fever virus is expected to manifest symptomatically within the first $72-96$ hours. ${ }^{10}$ Lassa fever virus has been shown to invade the placenta ${ }^{6}$ although pathologic examinations of the placenta in these cases were not done due to late diagnosis in

Table 2. Laboratory parameters, treatment and outcome of neonatal Lassa fever.

\begin{tabular}{|c|c|c|c|c|c|c|}
\hline Variables & Case 1 & Case 2 & Case 3 & Case 4 & Case 5 & Case 6 \\
\hline \multicolumn{7}{|l|}{ Laboratory parameters } \\
\hline Packed cell volume & $38 \%$ & $28 \%$ & $33 \%$ & $45 \%$ & ND & ND \\
\hline $\begin{array}{l}\text { White blood cell count } \\
\text { Total WBC } \\
\text { Neutrophil } \\
\text { Lymphocytes } \\
\text { Monocytes }\end{array}$ & $\begin{array}{c}7.5 \times 10^{9} / \mathrm{L} \\
39 \% \\
39 \% \\
21 \%\end{array}$ & $\begin{array}{l}\text { ND } \\
\text { ND } \\
\text { ND } \\
\text { ND }\end{array}$ & $\begin{array}{c}\text { ND } \\
68 \% \\
23 \% \\
7 \%\end{array}$ & $\begin{array}{c}70 \times 10^{9} / \mathrm{L} \\
21 \% \\
66.5 \% \\
8.2 \%\end{array}$ & $\begin{array}{l}\text { ND } \\
\text { ND } \\
\text { ND } \\
\text { ND }\end{array}$ & $\begin{array}{l}\text { ND } \\
\text { ND } \\
\text { ND } \\
\text { ND }\end{array}$ \\
\hline Platelet count & $236 \times 10^{9} / \mathrm{L}$ & ND & $182 \times 10^{9} / \mathrm{L}$ & ND & ND & ND \\
\hline PT & ND & ND & ND & Prolonged (60 seconds) & ND & ND \\
\hline APPT & ND & ND & ND & Prolonged (103 seconds) & ND & ND \\
\hline $\begin{array}{l}\text { RT-PCR (Days) } \\
\text { At birth } \\
\text { Subsequent } \\
\text { Subsequent }\end{array}$ & $\begin{array}{c}\text { Negative } \\
\text { Negative ( } 5^{\text {th }} \text { day) }\end{array}$ & $\begin{array}{c}\text { ND } \\
\text { Positive (post mortem) }\end{array}$ & $\begin{array}{c}\text { Negative } \\
\text { Negative (day 6) } \\
\text { Negative (day 23) }\end{array}$ & $\begin{array}{c}\text { ND } \\
\text { Positive (post mortem) }\end{array}$ & $\begin{array}{c}\text { ND } \\
\text { Positive (post mortem) }\end{array}$ & $\begin{array}{c}\text { Negative } \\
\text { Negative (day 7) }\end{array}$ \\
\hline $\begin{array}{c}\text { Treatment given } \\
\text { Supportive } \\
\text { Ribavirin } \\
\text { Antibiotic } \\
\end{array}$ & $\begin{array}{l}\text { Yes } \\
\text { Yes } \\
\text { Yes }\end{array}$ & $\begin{array}{l}\text { Yes } \\
\text { No } \\
\text { Yes }\end{array}$ & $\begin{array}{l}\text { Yes } \\
\text { Yes } \\
\text { Yes }\end{array}$ & $\begin{array}{l}\text { Yes } \\
\text { No } \\
\text { Yes }\end{array}$ & $\begin{array}{l}\text { Yes } \\
\text { No } \\
\text { Yes }\end{array}$ & $\begin{array}{l}\text { Yes } \\
\text { No } \\
\text { Yes }\end{array}$ \\
\hline Outcome & Died & Died & Alive & Died & Died & Alive \\
\hline Duration of hospital stay & 11 days & 3 days & 25 days & 3 days & 12 hours & 9 days \\
\hline
\end{tabular}

* PT: prothrombin time; APPT: activated partial thromboplastin time.

Table 3. Maternal characteristics of subjects exposed to Lassa virus or with confirmed neonatal Lassa fever.

\begin{tabular}{|c|c|c|c|c|c|c|}
\hline Variables & Case 1 & Case 2 & Case 3 & Case 4 & Case 5 & Case 6 \\
\hline Lassa RT-PCR positive & Yes & ND & Yes & No & ND & Yes \\
\hline Timing of diagnosis & Before delivery & ND & Before delivery & Post delivery & ND & Before delivery \\
\hline Ribavirin given & Yes & No & Yes & No & No & Yes \\
\hline Mode of delivery & SVD & SVD & SVD & EMLSCS & SVD & SVD \\
\hline Contact with baby & No & No & No & No & Yes & No \\
\hline Breastfeeding started & No & No & No & No & Yes & No \\
\hline Maternal outcome & Alive & Died & Alive & Alive & Alive & Alive \\
\hline
\end{tabular}

SVD: Spontaneous vaginal delivery; EMLSCS: Emergency lower segment caesarian. 
cases 2, 4 and 5 with neonatal LF confirmed postmortem. Lassa RT-PCR could not be done in the mother of case 2 who died two days after discharge from referral hospital. It is possible that the cause of her death might have been LF as the mother had antepartum haemorrhage which is a classical presentation in parturient females. ${ }^{6}$ In case 4 , the mother was earlier managed in our facility for malaria in pregnancy at 36 weeks GA. It is also possible that she might have presented with a mild form of LF since Lassa RTPCR was not done during the illness to establish a diagnosis of LF. It is known that Lassa fever can masquerade as other febrile illnesses such as malaria and if mild and non-haemorrhagic at the time, might go undiagnosed as in this case. ${ }^{8}$ However, the mother's blood sample tested negative to Lassa RT-PCR twice when her baby was diagnosed with LF postpartum. The reason for this conflicting result could not be established. There have been instances of persistent false-negative tests of Lassa fever in patients presenting with classic symptoms of the disease and many of these patients have been managed as Lassa fever and they recovered. ${ }^{11}$ It is also known that with highly diverse pathogens such as Lassa virus, genetic diversity can be problematic for nucleic acid-based assays, as even a single nucleotide variant in one of the primers can have a significant negative impact on assay sensitivity depending on the location of the nucleotide variant. ${ }^{9}$ This may affect the demonstration of positivity of a particular symptomatic case. In case 5 , the mother who appeared healthy and breastfed her baby refused to consent to be screened for Lassa fever, however the baby tested positive. Although the disease in pregnant women can have a fatal course, it is likely these mothers may have been asymptomatic carriers of the Lassa virus as about $80 \%$ of people have the mild disease or no observable symptoms while the remaining $20 \%$ have severe multisystem involvement. ${ }^{5}$ Therefore, vertical transmission cannot be ruled out in these cases. In such cases, evaluation of placenta may have yielded positive result as LV is known to seed in placenta. ${ }^{6}$ The evaluation of placenta was not done in cases 2, 5 and 6 with neonatal LF as the diagnosis was confirmed in these babies postmortem when the placentae had been discarded. More so, cases 2 and 5 were delivered outside our facility.

Symptoms of Lassa fever in adults include gradual onset of fever, weakness, malaise, and later sore throat, myalgia, and severe prostration as the illness progresses. More severe cases result in vomiting, hemorrhage, shock, encephalitis and death. Similar findings are seen in children. Bleeding manifestations seen in less than a third of patients signal poor prognosis. ${ }^{12}$ In the three newborns that had a late diagnosis of Lassa fever, the commonest clinical features observed were bleeding from orifices, tachypnea, respiratory distress, lethargy and pallor. Fever was reported in only two of them. Additionally, cases 4 and 5 had seizures and lethargy pointing to the possibility of encephalitis which is also one of the manifestations of severe cases of LF. ${ }^{12}$ Death was observed in the three newborns that had bleeding showing bleeding as a poor prognostic feature of LF in newborn babies. It is also possible that these newborns had co-existing morbidities as detailed investigations were not done to thoroughly exclude other suspected differentials. This finding is contrary to reports of some researchers in five neonates with suspected Lassa virus infection. They observed fever in all of them, bleeding in one whereas generalized swelling associated with abdominal distension and bleeding, a condition referred to as swollen baby syndrome was reported in three neonates. ${ }^{12,14}$ The implication of this is that effort should be made to exclude Lassa fever disease in any newborn presenting with fever and bleeding from any orifice irrespective of mothers' clinical status in high endemic areas.
Clinical diagnosis of Lassa fever is usually difficult due to the varied and non-specific symptoms associated with it. Diagnosis can be made using immunofluorescent antibody or enzyme-linked immunosorbent assay which detects an increase in antibody titer or the presence of specific IgM and IgG as well as Lassa antigen. ${ }^{15,16}$ Reverse transcription-polymerase chain reaction (RT-PCR) is the gold standard for Lassa fever confirmation and currently in use in Nigeria with a sensitivity of $100 \%$ in detecting the local strains of the Lassa virus. ${ }^{17}$ This method of diagnosis was utilized in all the neonates and consenting mothers. Other effects of illness include lymphocytopenia, thrombocytopenia, elevated aspartate aminotransferase level, and coagulation abnormalities, which are maximal 10-11 days after the onset of symptoms. ${ }^{18}$ Full blood count done in some of the newborns did not demonstrate lymphopenia or thrombocytopenia. Case 4 rather had lymphocytosis in addition to prolonged prothrombin time and activated partial thromboplastin time.

In our centre, maternal diagnosis of Lassa fever raises the suspicion of Lassa fever in a newborn. Cases 2, 4 and 5 had confirmed diagnosis of Lassa fever while cases 1, 3 and 6 tested negative to Lassa RT-PCR. Case 4 mother had negative PCR results despite repeat testing. This raised a lot of concern about the source of infection in the newborn as the baby was delivered in our facility and immediately admitted into the neonatal unit without having any contact with the mother. No sick health worker was caring for the baby or was there any other admitted neonate with suspected Lassa fever. Possibility of an asymptomatic carrier of Lassa fever virus having contact with the baby could not be ruled out in this case. Further screening of health workers to identify any asymptomatic carrier was also not done. Cases 2 and 5 mothers were not tested. Considering the early onset of symptoms in these newborns, vertical transmission as the source of infection is strongly suspected.

Treatment with intravenous ribavirin is particularly useful in decreasing Lassa fever mortality. Its administration within the first 6 days of illness has been shown to decrease the mortality of severe Lassa fever from $55 \%$ to $5 \% .{ }^{4}$ Supportive treatment in form of fluid and electrolyte management is often necessary. Surviving Lassa fever without antiviral treatment using ribavirin is perceived to be rare. ${ }^{6}$ Ajayi et al. ${ }^{8}$ reported a case of an adult that survived LF without ribavirin therapy. In pregnancy, the Lassa virus causes high maternal and fetal mortality due to high viral concentrations in the maternal blood, placenta, and fetal tissue. Maternal death and/or foetal loss occurs in more than $80 \%$ of cases during the third trimester contributing to high neonatal mortality in West Africa. ${ }^{5,6,12}$ In this study, a good neonatal outcome was recorded in two out of the three babies whose mothers' Lassa fever was diagnosed with all of them having received ribavirin therapy before their delivery. None of the babies contracted the virus showing the benefit of prompt diagnosis and commencement of ribavirin therapy in the mother before delivery and its possibility in preventing vertical transmission of the virus. The only recorded mortality in this group was related to problems of prematurity. This is at variance with an earlier report in Sierra Leone where $87 \%$ fatality rate occurred in neonates born to infected mothers. ${ }^{6}$ Administration of ribavirin therapy to pregnant women as practiced currently may have accounted for the good neonatal outcome in our study as this was not practiced in the earlier study in Sierra Leone. ${ }^{6}$

On the contrary, cases 2, 4 and 5 with neonatal LF had a fatal outcome. This was due to late suspicious of Lassa fever in these newborns, hence ribavirin therapy was not given to them accounting for the $100 \%$ mortality recorded in them. Also, the diagnosis of LF was not established in the mothers before delivery. Cases 2 and 
4 died three days after birth while case 5 died at 12 days of age. This corroborates earlier studies that showed $100 \%$ mortality in newborns occurring within hours to 18 days of birth to Lassa virusinfected pregnant women who did not receive ribavirin in pregnancy. ${ }^{6,8}$ Mothers of these newborns did not receive ribavirin therapy to prevent vertical transmission.

The findings from this study call for a review of existing protocol for diagnosis of Lassa fever in pregnant mothers and establishment of neonatal Lassa fever management protocol to ensure prompt diagnosis and early commencement of ribavirin therapy in confirmed cases so as achieve a good neonatal outcome.

\section{Conclusions}

This case series has emphasized the importance of a high index of suspicion of neonatal Lassa fever by the health workers, prompt diagnosis of Lassa fever in pregnant women, and early ribavirin treatment that reduces the rate of vertical transmission of the virus to the newborn. Since LFD has a fatal outcome in neonates, there may be a need to timely commence ribavirin therapy in highly suspected neonatal LF cases while waiting for laboratory confirmation. These measures will help reduce perinatal and neonatal mortality contributed by the disease.

\section{References}

1. Ogbu O, Ajuluchukwu E, Uneke CJ. Lassa fever in West African sub-region: An overview. J Vector Borne Dis 2007; 44:1-11.

2. Frame JD, Baldwin JM, Gocke D. Lassa fever, a new virus disease of man from West Africa. I. Clinical description and pathological findings. Am J Trop Med Hyg 1970;19:670-6.

3. Fisher-Hoch SP, McCormick JB. Lassa fever vaccine: A review. Expert Rev Vaccines 2004;3:103-11.

4. McCormick JB, King IJ, Webb PA, et al. A case-control study of the clinical diagnosis and course of Lassa fever. J Infect Dis 1987; 155:445-55.

5. World Health Organization. WHO Lassa Fever sheet. 2017. Accessed: 2020 Apr 13. Available from: https://www.who. int/csr/don/28-june-2017-lassa-fever-nigeria/en/.

6. Price ME, Fisher-Hoch SP, Craven RB, McCormick JB. A prospectively study of maternal and fetal outcome in acute Lassa fever infection during pregnancy. $\mathrm{Br}$ Med J 1988;284:584-7.

7. Branco LM, Boisen ML, Andersen KG, et al. Lassa hemorrhagic fever in a late term pregnancy from northern sierra leone with a positive maternal outcome: case report. Virol J 2011;404.

8. Ajayi NA, Ukwaja KN, Ifebunandu NA, et al. Lassa fever full recovery without ribavarin treatment: a case report. Afr Health Sci 2014;14:1074-7.

9. Stadhouders R, Pas SD, Anber J, et al. The Effect of PrimerTemplate Mismatches on the Detection and Quantification of Nucleic Acids Using the 5' Nuclease Assay. J Mol Diagnostics 2010;12:109-17.

10. Chan GJ, Lee AC, Baqui AH, et al. Prevalence of early-onset neonatal infection among newborns of mothers with bacterial infection or colonization: a systematic review and meta-analysis. BMC Infect Dis Dis 2015;15:813. doi:10.1186/s12879015-0813-3.

11. Eze KC, Salami TA, Kpolugbo JU. Acute abdominal pain in patients with lassa fever: Radiological assessment and diagnostic challenges. Niger Med J 2014;55:195-200.

12. Adewuyi GM, Fowotade A, Adewuyi BT. Lassa fever: another infectious menace. African J Clin Exp Microbiol 2009;10:14455.

13. Monso MH, Cole AK, Frame JD, et al. Pediatric Lassa fever: A review of 33 Liberian cases. Am J Trop Med Hyg 1987;36:408-15.

14. Monath TP, Mertens PE, Patton R, et al. A hospital epidemic of Lassa fever in Zorzor, Liberia. Am J Trop Med Hyg 1972;22:773-9.

15. Nasir IA, Sani FM. Outbreaks, pathogen containment and laboratory investigations of Lassa fever in Nigeria: how prepared are we? Int J Trop Dis Heal 2015;10:1-10.

16. Centers for Disease Control and Prevention (CDC) Lassa Fever, CDC fact sheet, CDC, June, 2014. Available from: http://www.cdc.gov/vhf/ lassa/.

17. Olschläger S, Lelke M, Emmerich $\mathrm{P}$, et al. Improved detection of Lassa virus by reverse transcription-PCR targeting the 5' region of S RNA. J Clin Microbiol 2010;48:2009-13.

18. Richmond JK, Baglole DJ. Lassa fever epidemiology, clinical features, and social consequences. Br Med J 2003;327:1271-5. 